\title{
IMPLEMENTASI UPAYA DIVERSI DALAM PENYELESAIAN TINDAK PIDANA PENCURIAN OLEH ANAK DI KABUPATEN BULELENG
}

\author{
Kadek Devi Selvian ${ }^{1}$, Ni Putu Rai Yuliartini ${ }^{1}$, Ketut Sudiatmaka \\ Jurusan IImu Hukum \\ Universitas Pendidikan Ganesha \\ Singaraja, Indonesia \\ e-mail: \{ selviandevi@yahoo.com ${ }^{1}$, raiyuliartini@gmail.com¹, \\ sudiatmaka58@gmail.com² $\}$
}

\begin{abstract}
Abstrak
Penelitian ini bertujuan untuk menganalisis, pelaksanaan upaya diversi dalam penyelesaian tindak pidana pencurian yang dilakukan oleh anak di kabupaten Buleleng dan faktor penghambat dan pendukung penerapan upaya diversi dalam penyelesaian tindak pidana pencurian yang dilakukan oleh anak di kabupaten Buleleng. Jenis penelitian yang digunakan yaitu penelitian hukum empiris. Penelitian ini menggunakan sifat penelitian deskripif kualitatif. Lokasi penelitian ini dilaksanakan di Polres Buleleng. Teknik pengumpulan data dilakukan dengan cara observasi, wawancara, studi dokumen. Hasil penelitian menunjukkan bahwa upaya diversi dapat berhasil dilakukan dalam perkara tindak pidana pencurian yang dilakukan oleh anak di kabupaten buleleng bila adanya musyawarah dan komunikasi yang baik atara kedua belah pihak dan akan berhasil bila ada kesepakatan antara dua belah pihak, dan diversi tidak berhasil dilakukan bila pihak korban merasa masih dirugikan terhadap perbuatan yang dilakukan pelaku, dan dari pihak pelaku tidak mau bertanggung jawab. Adapun faktor penghambat upaya diversi di kabupaten Buleleng dikarenakan keterbatasan bentuk dari tindak lanjut penetapan diversi yang diterapkan oleh Kepolisian Resort Buleleng, tindak lanjut yang dilakukan hanya dalam bentuk pengembalian kepada orang tua. Berdasarkan hal tersebut harus adanya faktor pendukung agar pelaksanaan diversi bisa berjalan secara optimal, dengan adanya tindakan lanjutan seperti menyerahkan anak kepada negara untuk mengikuti pendidikan, pembinaan, dan latihan kerja agar anak dapat hidup dengan mandiri tanpa merugikan orang lain.
\end{abstract}

Kata Kunci: Tindak Pidana, Upaya Diversi, Pencurian, Anak.

\begin{abstract}
This study aims to analyze the implementation of diversion efforts in the settlement of criminal acts of theft committed by children in Buleleng district and the obstacle factors and support the implementation of diversion attempts in the settlement of crime theft committed by children in Buleleng district. The type of research used is empirical legal research. This research uses qualitative descriptive research. The location of this research was conducted at Polres Buleleng. The research data was collected by using observation, interview, document study. The results show that the diversion effort can be successfully done in the case of criminal theft committed by the child in Buleleng district if there is good deliberation and communication between both parties and will succeed if there is agreement between two parties. diversion can not be successfully done if the victim feels that he is still harmed by the acts committed by the perpetrator and the perpetrator does not want to be responsible. The factor inhibiting diversion efforts in Buleleng district is due to the limited form of follow-up to the determination of diversion attempts applied by the Kepolisian Resort Buleleng, the follow-up done only in the form of return to the parents. Based on this, there must be a supporting factor in order that the implementation of diversion can be run optimally in the presence of follow-up actions such as giving the child to the state to follow education, coaching and work training so that children can live independently without harming others.
\end{abstract}

Keywords: Crime, Diversion Efforts, Theft, Child 


\section{Pendahuluan}

Anak adalah sesuatu yang sangat penting karena anak merupakan potensi nasib manusia hari mendatang, dialah yang ikut berperan menentukan sejarah bangsa sekaligus cerminan sikap hidup bangsa pada masa mendatang. Untuk itu membicarakan tentang anak maka tidak terlepas dari perlindungannya yang tidak akan pernah berhenti sepanjang sejarah kehidupan, karena anak adalah generasi yang dipersiapkan sebagai subjek pelaksanaan pembangunan yang berkelanjutan dan pemegang kendali masa depan suatu negara.

Hal tersebutlah menyebabkan anak sangat memerlukan suatu pembinaan dan perlindungan terhadap anak dalam rangka menjamin suatu pertumbuhan dan perkembangan fisiknya, sosial, maupun mentalnya secara utuh, serasi, selaras dan juga seimbang. Untuk melaksanakan pembinaan dan perlindungan terhadap anak, diperlukan suatu pendidikan dan tanggung jawab dari orang tua yang tidak boleh diabaikan. Hal ini dikarenakan orang tua merupakan yang pertama-tama bertanggungjawab atas terwujudnya kesejahtraan anak baik secara rohani, jasmani maupun sosial.

Perlindungan anak Indonesia berarti melindungi potensi sumber daya insani dan membangun manusia Indonesia seutuhnya, menuju masyarakat yang adil dan makmur, berdasarkan Pancasila dan UUD 1945 (Nashriana,2011:1). Perlindungan anak menurut Pasal 1 butir 2 Undang-Undang Nomor 35 Tahun 2014 tentang perlindungan anak, bahwa perlindungan anak adalah segala kegiatan untuk menjamin dan melindungi anak dan hak- haknya agar dapat hidup, tumbuh, berkembang, dan berpartisipasi secara optimal sesuai dengan harkat dan martabat kemanusiaan, serta mendapat perlindungan dari kekerasan dan diskriminasi.

Perlindungan terhadap anak sangat diperlukan suatu dukungan, baik yang menyangkut kelembagaan maupun menyangkut perangkat hukum yang lebih mantap dan memadai. Hukum itu merupakan rangkaian peraturan-peraturan mengenai tingkah laku orang-orang sebagai anggota masyarakat, dan tujuan hukum itu adalah mengadakan keselamatan, kebahagiaan, dan tata tertib di dalam masyarakat (Gultom2010:3).

Hukum sebagai kontrol, pengendali dan pemandu kehidupan bermasyarakat, agar terciptanya suatu tatanan kehidupan berbangsa dan bernegara yang aman, tertib, dan adil. Sehingga sangat diperlukan suatu jaminan hukum bagi kegiatan perlindungan anak. Kepastian hukum perlu diusahakan demi kegiatan kelangsungan perlindungan anak dan mencegah penyelewengan yang membawa akibat negatif yang tidak diinginkan dalam pelaksanaan kegiatan perlindungan anak.

Dasarnya anak tidak dapat melindungi diri sendiri dari berbagai macam tindakan yang menimbulkan kerugian mental, fisik, sosial dalam berbagai bidang kehidupan dan penghidupan. Sehingga anak perlu dibantu oleh orang lain dalam melindungi dirinya, mengingat situasi dan kondisinya, khususnya dalam pelaksanaan Peradilan Pidana Anak yang asing bagi dirinya. Peradilan Pidana Anak mengandung pengertian proses pemeriksaan perkara pidana anak, mulai dari tahap penyidikan atau penyelidikan, penuntutan, persidangan, dan pemasyarakatan. Anak perlu mendapat perlindungan dari kesalahan penerapan peraturan

perundang-undangan yang diberlakukan terhadap dirinya, yang menimbulkan kerugian mental, fisik, sosial. Perlindungan anak dalam hal ini disebut perlindungan hukum. (Gultom, 2010:2).

Diundangkannya Undang-undang Republik Indonesia Nomor 11 Tahun 2012 tentang Sistem Peradilan Pidana Anak (yang selanjutnya di sebut UU No 11 Tahun 2012) merupakan pengganti dari Undang- undang nomor 3 Tahun 1997 tentang Pengadilan Anak (Lembaran Negara Republik Indonesia Tahun 1997 Nomor 3, Tambahan lembaran Negara Republik Indonesia Nomor 3668) yang dilakukan dengan tujuan agar terwujud peradilan yang benar-benar menjamin perlindungan kepentingan terbaik terhadap Anak yang 
berhadapan dengan hukum sebagai penerus bangsa Indonesia (Sepud, 2013:3). Sistem Peradilan Pidana Anak berbeda dengan Sistem Peradilan Pidana bagi orang dewasa dalam berbagai segi.

Peradilan Pidana Anak meliputi segala aktivitas pemeriksaan dan pemutusan perkara yang menyangkut kepentingan anak. Menekankan atau memusatkan pada kepentingan anak harus merupakan pusat perhatian dalam Peradilan Pidana Anak. Dalam pembentukan peraturan perundangundangan yang mengatur tentang Peradilan

Pidana Anak, hak-hak anak merupakan dasar pembentukan peraturan perundangundangan tersebut. Ini berarti Peradilan Pidana Anak yang adil memberikan perlindungan terhadap hak-hak anak, baik sebagai tersangka, terdakwa, maupun sebagai terpidana/narapidana, sebab perlindungan terhadap hak-hak anak ini merupakan tonggak utama dalam Peradilan Pidana Anak dalam negara hukum (Gultom, 2010:6).

Berdasarkan suatu sudut pandang dari psikologis, berbagai tindakan dan sikap sewenang-wenang terhadap anak, membuat mereka menjadi anak-anak yang bermasalah sehingga mengganggu proses perkembangan atau pertumbuhan secara sehat (Agoes,2014:5). Hal ini tentu tidak terlepas dari semakin kompleksnya masalah-masalah yang sedang dihadapi anak-anak jaman sekarang, ditambah faktor-faktor penunjang untuk terjadinya proses belajar secara tidak langsung, seperti tayangan-tayangan kekerasan di layar kaca, sampai berita kekerasan yang sering muncul. Sementara itu dari diri seorang anak proses meniru paling dominan memberikan pengaruh terhadap dirinya (Zaimir,2014:5).

Lingkungan yang negatif membuat anak terdorong ikut melakukan suatu perbuatan yang negatif, sehingga sering menemukan anak yang tersangkut masalah hukum, baik anak itu selaku korban tindak pidana maupun sebagai pelaku tindak pidana. Anak yang berhadapan dengan hukum adalah anak yang berkonflik dengan hukum, anak yang menjadi korban tindak pidana, dan anak yang menjadi saksi tindak pidana. Anak yang berkonflik dengan hukum yang selanjutnya disebut anak adalah anak yang telah berumur 12 (dua belas) tahun, tapi belum berumur 18 (delapan belas) tahun yang diduga melakukan tindak pidana, hal ini disebutkan dalam Pasal 1 Ayat (2) dan 3 UU No 11 Tahun 2012. Anak sebagai pelaku tindak pidana harus tetap dilindungi dan diperhatikan hak-haknya agar tidak merusak masa-masa pertumbuhan anak yang bersangkutan. Pada dasarnya anak mempunyai berbagai hak asasi anak yang harus diimpelemntasikan dalam kehidupan dan penghidupan mereka.

Kasus-kasus yang melibatkan anak sebagai pelaku suatu tindak pidana berbeda dengan pelaku tindak pidana dewasa. Anak sebagai pelaku tindak pidana yang dijatuhi pidana untuk dibina dalam suatu Lembaga Pemasyarakatan Anak perlu yang mendapat penanganan khusus dalam menjalani masa pidananya. Kasus tindak pidana yang melibatkan anak dibawah umur belakangan ini sangatlah banyak terjadi dalam masyarakat (Frederica,2017:62), salah satunya adalah tindak pidana pencurian.

Tindak pidana pencurian adalah suatu tindakan yang dilakukan oleh seseorang dengan mengmbil barang orang lain dengan maksud memiliki dengan cara melawan hukum (Erdianto,2010:53). Tindak pidana pencurian diatur dalam Pasal 362 KUHP yang berbunyi:

"Barangsiapa mengambil sesuatu barang, yang sama sekali atau sebagian termasuk kepunyaan orang lain, dengan maksud akan memiliki barang itu dengan melawan hak dihukum karena pencurian dengan hukuman penjara selama-lamanya lima tahun atau denda sebanyak-banyaknya Rp. 900"

Berdasarkan penjelasan dalam Pasal 362 KUHP menurut Suwandy tentang pencurian terdiri dari beberapa unsur, yaitu barangsiapa, mengambil, sesuatu barang, yang seluruh atau sebagaian kepunyaan orang lain, dengan maksud untuk memiliki secara melawan hukum. Berdasarkan unsur-unsur tersebut sehingga seseorang bisa dinyatakan terbukti melakukan tindak pidana pecurian harus telah terbukti 
memenuhi unsur dari tindak pencurian terebut.

Tindak pidana pencurian merupakan kejahatan yang sangat mengganggu kenyamanan dari masyarakat, hal ini dapat

berdampak pada beberapa aspek yaitu ekonomi, sosial, dan lingkungan. Pencurian itu sendiri merupakan suatu bentuk kejahatan sosial yang sulit dihilangkan, hal ini disebabkan karena semakin meningkatnya suatu kebutuhan dan kurang bijaknya seseorang menjalani kehidupannya dalam bermasyarakat.

Pencurian tidak hanya dilakukan oleh orang dewasa bahkan pencurian dilakukan oleh orang yang masih dibawah umur yang dikategorikan sebagai anak. Pencurian yang dilakukan oleh anak seringkali dilakukan karena kondisi psikologi anak yang masih belum stabil, bahkan dilakukan

karena ajakan maupun bujukan bahkan paksaan dari orang dewasa. Oleh karena itu perlindungan hukum terhadap anak yang tersangkut tindak pidana sangat diperlukan.

Pencurian yang dilakukan oleh anak banyak dijumpai di kota-kota besar dan bahkan sudah mulai merambat di kota-kota kecil yang ada di setiap provensi. Di kabupaten buleleng contohnya, pencurian yang dilakukan oleh anak marak terjadi. Hal inilah yang menyebabkan penulis melakukan penelitian skripsi di Kabupaten Buleleng. Alasan penulis melakukan penelitian di Kabupaten Buleleng dikarenakan pertumbuhan penduduk di kabupaten buleleng yang semakin

meningkat maka akan mempengaruhi meningkatnya kebutuhan hidup, alasan yang kedua adalah di mana pertumbuhan teknologi yang begitu pesat serta munculnya berbagai produk elektronik canggih membuat banyak orang menginginkannya. Kondisi inilah yang membuat sebagian anak di kabuapaten Buleleng menginginkan segala sesuatunya secara cepat meskipun dengan cara yang tidak benar yaitu dengan mencuri. Tentu hal

ini sangat mengkhawatirkan, dengan maraknya terjadi kasus pencurian yang dilakukan oleh anak, hal ini akan menimbulkan keresahan dan kerugian bagi masyarakat dan anak itu sendiri. Berbagai upaya sudah dilakukan oleh kepolisian dalam menanggulangi pencurian yang dilakukan oleh anak di kabupaten buleleng, seperti melakukan sosialisasi dengan memberikan tentang pendidikan karakter dan sanksi-sanksi yang akan dikenakan jika melakukan tindak pidana pencurian.

Pencurian yang dilakukan oleh anak sering terjadi di Kabupaten Buleleng khususnya, dari tahun 2015 sampai dengan 2017 banyak terjadinya tindak pidana pencurian yang dilakukan oleh anak, hal ini bisa dilihat dari data sebagai berikut:

Tabel : 01 Data Tindak Pidana Terhadap Anak Sebagai Pelaku

Data Kekerasan Terhadap Anak Sebagai Pelaku Tahun 2015-2017 di Kabupaten Buleleng

\begin{tabular}{|l|l|c|c|c|l|}
\hline N & \multicolumn{1}{|c|}{$\begin{array}{c}\text { Jenis } \\
0\end{array}$} & $\begin{array}{l}\text { Tindak } \\
\text { Pidana }\end{array}$ & $\begin{array}{c}\text { Jumlah } \\
2015- \\
2017\end{array}$ & \multicolumn{3}{|c|}{ Ket } \\
\cline { 3 - 6 } & 2015 & 2016 & 2017 & \\
\hline 1 & $\begin{array}{l}\text { Pencurian } \\
\text { Biasa }\end{array}$ & 3 & 2 & 1 & $\begin{array}{l}5 \\
\text { Dive } \\
\text { rsi }\end{array}$ \\
\hline 2 & $\begin{array}{l}\text { Pencurian } \\
\text { Motor }\end{array}$ & 3 & 7 & 1 & $\begin{array}{l}11 \\
\text { Dive } \\
\text { rsi }\end{array}$ \\
\hline 3 & $\begin{array}{l}\text { Pencurian } \\
\text { Berat }\end{array}$ & 2 & - & 2 & $\begin{array}{l}3 \\
\text { Dive } \\
\text { rsi }\end{array}$ \\
\hline & Jumlah & 8 & 9 & 4 & $\begin{array}{l}19 \\
\text { Dive } \\
\text { rsi }\end{array}$ \\
\hline
\end{tabular}

Sumber: Data Kasus Kekerasan Terhadap Anak Sebagai Pelaku di Sat Reskrim Polres Buleleng

Melihat fakta yang ada di kabupaten Buleleng, pencurian anak sebagai salah satu wujud dari kenakalan anak terjadi karena berbagai alasan. Alasan-alasan tersebut, seperti kurangnya kasih sayang dan perhatian dari orang tua, keinginan untuk memiliki sesuatu, kondisi psikologi anak yang masih belum setabil sehingga mudah terpengaruh dari teman sepermainannya. Dari kondisi ini sehingga anak perlu mendapat perlindungan untuk menjamin hak-haknya. Prinsip perlindungan anak adalah prinsip non diskriminasi yaitu lebih mengutamakan suatu kepentingan terbaik bagi anak dan hak untuk hidup, perkembangan, dan kelangsungan hidup 
maka diperlukan proses pengalihan penyelesaian perkara dari proses peradilan ke proses diluar peradilan pidana atau yang sering disebut Diversi.

Setiap penyidik, penuntut umum, dan hakim dalam memeriksa anak wajib mengupayakan diversi, diversi dapat dilaksanakan di setiap tahap dalam sistem peradilan pidana, mulai dari tahap penyidikan, tahap penuntutan, dan tahap persidangan. Diversi dapat dilaksanakan dalam hal tindak pidana yang dilakukan diancam dengan pidana penjara di bawah 7 (tujuh) tahun dan bukan merupakan pengulangan tindak pidana, hal ini dijelaskan dalam peraturan pemerintah republik Indonesia Nomor 65 Tahun 2015 tentang pedoman pelaksanaan diversi dan penanganan anak yang belum berumur 12 (dua belas tahun).

Tujuan dari diversi menurut UU No 11 Tahun 2012 yaitu untuk mencapai perdamaian anatara korban dan anak, menyelesaiakan perkara anak di luar proses peradilan, menghindarkan anak dari perampasan kemerdekaan, mendorong masyarakat untuk berpartisipasi, dan menanamkan rasa tanggung jawab kepada anak. Bagi anak lembaga pemasyarakatan bukanlah suatu jalan untuk menyelesaiakan permasalahan anak, malah sebaliknya dalam lembaga pemasyarakatan rawan terjadinya pelanggaran-pelanggaran terhadap hak anak. Oleh sebab itu diversi adalah suatu pertimbangan yang sangat penting dalam suatu penyelesaian perkara pidana yang dilakukan oleh anak.

Upaya diversi pada tahap penyidikan sering menemukan kegagalan terutama pada tahun 2015 sampai 2017 dikarnakan sering tidak menemukan kesepakatan untuk melakukan upaya diversi dari korban, dikarnakan korban sering merasa dirugikan oleh perbuatan pelaku sehingga korban sering berfikir karena ia merasa dirugikan maka harus dijatuhi pidana sesuai dengan tindak pidananya. (Frederica, 2017:7). Pada penelitian ini peneliti lebih membahas implementasi upaya diversi dalam penyelesaian tindak pidana pencurian yang dilakukan oleh anak di kabupaten Buleleng.

\section{Metode Penelitian}

Jenis penelitian yang digunakan dalam penelitian ini adalah penelitian hukum empiris Dalam hal ini mengenai Implementasi Upaya Hukum Diversi Dalam Penyelesaian Tindak Pidana Pencurian yang Dilakukan oleh Anak akhir-akhir ini dalam penerapannya banyak terjadi kegagalan dalam pengupayaan diversi, seperti halnya tindak pidana pencurian yang terjadi dari tahun 2015 sampai dengan tahun 2017 di Reskrim kabupaten buleleng. Sifat penelitian yang digunakan adalah deskriptif dimana menggambarkan secara nyata mengenai keadaan-keadaan atau gejalagejala yang ada dalam masyarakat. Data dan sumber data yang digunakan ada dua jenis data primer dan data sekunder, data sekunder ini berupa bahan hukum primer, bahan hukum sekunder, dan bahan hukum tersier, penulis menggunakan tiga jenis pengumpulan data, yaitu teknik studi dokumen, teknik wawancara, dan teknik observasi atau pengamatan. Teknik penentuan sampel penelitiannya menggunakan teknik non robability sampling artinya dalam penelitian ini tidak ada ketentuan pasti berapa sampel harus diambil agar dapat mewakili populasinya (Waluyo,2008:46). Bentuk dari penerapan teknik non probability sampling dalam penelitian ini adalah Purposive Sampling. Dan data penelitian ini diolah dan dianalisis secara kualitatif.

\section{Hasil dan Pembahasan \\ Pelaksanaan Upaya Diversi Dalam Penyelesaian Tindak Pidana Pencurian yang Dilakukan oleh Anak di Kabupaten Buleleng.}

Keuntungan dari diversi jika dilakukan pada tahap penyidikan oleh kepolisian, yang pertama kepolisian merupakan satusatunya lembaga penegak hukum dalam subsistem peradilan pidana yang mempunyai jaringan sampai di tingkat kecamatan. Dengan demikian, secara struktural lembaga kepolisian merupakan satu-satunya lembaga penegak hukum yang paling dekat dan yang paling mudah dijangkau oleh masyarakat (Sinaga, 2017:138). 
Kedua, secara kuantitas aparat kepolisian jauh lebih banyak dibandingkan dengan aparat penegak hukum lainnya. Sekalipun bahwa tidak semua aparat kepolisian mempunyai wewenang untuk menangani tindak pidana yang dilakukan oleh anak, tetapi ketersediaan personil yang cukup memadai juga akan sangat membantu proses penyelesaian tindak pidana yang dilakukan oleh anak (Sinaga, 2017:139).

Ketiga, mengingat lembaga kepolisian merupakan aparat penegak hukum pertama yang bergerak dalam proses peradilan pidana, maka diversi di tingkat kepolisian mempunyai arti memberikan jaminan kepada anak untuk sedini mungkin dihindarkan dari hal yang berkaitan dengan proses peradilan pidana. Dengan demikian, dampak negatif akibat anak yang beruhungan dengan aparat penegak hukum dapat diminimalisir (Sinaga, 2017:139).

Proses diversi ditingkat penyidikan dimulai setelah menerima laporan polisi. Penyidik membuat surat untuk meminta saran tertulis dari petugas pembimbing kemasyarakatan. Hasil penelitian dari pembimbing kemasyarakatan wajib diserahkan oleh pembimbing kemasyarakatan kepada penyidik dalam waktu paling lama tiga kali duapuluh empat jam setelah permintaan dari penyidik diterima. Penyidik mulai mengupayakan diversi dalam waktu paling lama tujuh hari setelah penyidikan dimulai (Sinaga, 2017:144).

Suatu tindak pidana pencurian yang pada awalnya banyak dilakukan oleh orang dewasa, namun saat ini banyak melibatkan anak-anak. Kejahatan tersebut dapat dilakukan karena keinginannya sendiri ataupun melibatkan orang dewasa. Kasus tindak pidana pencurian di Kabupaten Buleleng meningkat dari tahun ke tahun hingga tahun 2017. Selama kurun waktu 3 (tiga) tahun mulai dari tahun 2015, kasus pencurian yang dilakukan oleh anak juga semakin tinggi, hal yang melatarbelakangi meningkatnya tindak pidana pencurian yang dilakukan oleh anak dikarenakan kebutuhan ekonomi yaitu adanya keinginan untuk mengikuti jaman sekarang namun dikarenakan terhimpitnya kondisi ekonomi keluarga, sehingga tidak dapat memenuhi keinginanya, maka tidak ada jalan lain dan butuh uang cepat maka mereka mencari cara yang cepat yaitu dengan mencuri.

Dapat dijelaskan mengenai faktorfaktor yang mempengaruhi anak melakukan tindak pidana pencurian, diantaranya:

1. Faktor ekonomi, yang berhubungan dengan masalah kemiskinan pada satu sisi dan keinginan untuk memenuhi kebutuhan pada sisi lainnya.

2. Faktor lingkungan, yang berhubungan dengan masalah perhatian kepada anak, baik dari lingkungan keluarga, lingkungan sekolah maupun lingkungan masyarakat.

3. Faktor pendidikan dan keterampilan, yang berhubungan dengan pola pendidikan yang diberikan kepada anak dan keterampilan yang dimiliki anak.

Faktor kemajuan teknologi, yang berhubungan dengan masalah-masalah penyalahgunaan manfaat peralatan teknologi seperti tayangan-tayangan televisi yang tidak mendidik. Anak akan terpengaruh pada apa yang ditawarkan atau ditayangkan di televisi sehingga ada keinginan memiliki sementara secara finansial belum mampu. Tindak pidana pencurian merupakan salah satu delik yang terkait dengan kekayaan. Di dalam KUHP, delik ini diatur dalam Pasal 362 sampai dengan Pasal 367.

Penyidikan terhadap perkara Anak dilakukan oleh Penyidik yang ditetapkan berdasarkan Keputusan Kepala Kepolisian Negara Republik Indonesia atau pejabat lain yang ditunjuk oleh Kepala Kepolisian Negara Republik Indonesia dalam Pasal 26 ayat (1) Undang-Undang Nomor 11 Tahun 2012.

Penyidik yang melakukan penyidikan terhadap kasus anak juga mempunyai beberapa syarat diantaranya Syarat untuk dapat ditetapkan sebagai Penyidik sebagaimana dimaksud pada ayat

(1) yaitu dalam Pasal 26 ayat (3) UndangUndnag Nomor 11 Tahun 2012 meliputi:

a. Telah berpengalaman sebagai penyidik, 
b. Mempunyai minat, perhatian, dedikasi, dan memahami masalah anak, dan

c. Telah mengikuti pelatihan teknis tentang peradian Anak

Penyidikan kasus pidana anak yang dilakukan oleh kepolisian sesuai dengan UU nomor 8 Tahun 1981 Tentang Hukum Acara Pidana (KUHAP) dan khususnya dalam penyidikan dan penyelidikan terhadap anak pelaku tindak pidana diatur dalam UU SPPA, dan UU Perlindungan Anak.

Di dalam perkara anak penyidik harus melibatkan Balai Pemasyarakatan (yang selanjutnya disebut BAPAS), pelaku/orang tua, korban, dan dinas sosial. Sebagaimana diketahui bahwa setiap anak yang berhadapan dengan hukum berhak mendapatkan perlindungan baik fisik, mental, maupun sosial sesuai dengan Undang-undang perlindungan anak (UU No 35 Tahun 2014).

tahapan yang harus dilaksanakan dalam proses pelaksanaan diversi yaitu, penyidik menerima laporan dari pelapor lalu penyidik membuat Berkas Acara Perkara (BAP), selanjutnya penyidik menyerahkan BAP kepada Balai Pemasyarakatan (Bapas). Setelah mendapatkan BAP dari penyidik, selanjutnya Bapas melakukan Penelitian Masyarakat (Litmas) di lingkungan rumah pelaku. Berdasarkan hasil litmas Bapas nantinya akan keluar surat rekomendasi dari Bapas, dimana surat rekomendasi tersebut bisa merupakan rekomendasi untuk diversi dan rekomendasi untuk tidak diversi. Selanjutnya penyidik selaku fasilitator akan memanggil para pihak untuk melakukan diversi. Sebelum melakukan diversi penyidik perlu melakukan wawancara dengan pelaku untuk mengetahui dan memahami motif pelaku melakukan tindak pidana tersebut, sehingga nantinya penyidik sebagai fasilitator dalam diversi akan lebih mudah untuk mengupayakan diversi berhasil mencapai kesepakatan.

Berdasarkan penelitian dan observasi dari beberapa kasus yang berhasil dilakukan di polres Buleleng, dapat disimpulkan diversi dapat berhasil dilakukan dalam perkara tindak pidana pencurian yang dilakukan oleh anak di kabupaten buleleng bila adanya musyawarah dan komunikasi yang baik atara kedua belah pihak dan akan berhasil bila ada kesepakatan anatara dua belah pihak, dimana pihak pelaku mau bertanggung jawab atas perbuatannya dan berjanji tidak akan mengulangi perbuatannya. Sedangkan pihak korban bersedia memafkan pelaku sesuai dengan ketentuan-ketentuan yang dikehendaki korban.

Berdasarkan penelitian dan observasi dari beberapa kasus yang tidak berhasil dilakukan di polres Buleleng, dapat disimpulkan diversi tidak dapat berhasil dilakukan dalam perkara tindak pidana pencurian yang dilakukan oleh anak di kabupaten buleleng bila pihak korban merasa masih dirugikan terhadap perbuatan yang dilakukan pelaku, hal ini dikarenakan pelaku tidak mampu melakukan ganti rugi karena perbuatan yang sudah ditimbulkan. Dan upaya diversi tidak berhasil dilakukan juga dikarenakan kurang adanya musyawarah dan komunikasi yang baik atara kedua belah

\section{Faktor Penghambat dan Penunjang Penerapan Upaya Diversi Dalam Penyelesaian Tindak Pidana Pencurian yang Dilakukan oleh Anak di Kabupaten Buleleng}

1. Faktor Penghambat Penerapan Upaya Diversi Dalam penyelesaian tindak Pidana Pencurian yang Dilakukan Oleh Anak di Kabupaten Buleleng.

Berdasarkan analisis yang dilakukan oleh peneliti di kabupaten Buleleng bahwa hal yang menyebabkan terhambatnya penerapan upaya diversi dalam penyelesaian tindak pidana pencurian yang dilakukan oleh anak dikabupaten buleleng pada dasarnya dikarenakan dalam proses penerapan diversi dalam sistem peradilan anak meliputi, 1) Kebutuhan yang semakin meningkat tidak sebanding dengan baik personel maupun fasilitas, 2) Pemahaman yang berbeda dalam penanganan anak berhadapan dengan hukum dan korban di antara aparat penegak hukum, 3) Kurangnya kerja sama antara pihak yang terlibat (aparat penegak hukum dan pekerja 
sosial anak), 4) Terbatasnya sarana dan prasarana penanganan anak berhadapan dengan hukum selama proses diversi.

Keterbatasan bentuk diversi yang diterapkan oleh Kepolisian Resort Buleleng dimana hanya dalam bentuk pengembalian kepada orang tua menjadikan proses diversi yang ditawarkan kepada korban bisa terancam gagal. Hal ini dikarenakan, bentuk diversi berupa pengembalian kepada orang tua merupakan proses terlemah dengan tidak ada proses pendidikan yang dilakukan terhadap pelaku tindak pidana anak seperti pendidikan atau kerja sosial. Kemungkinan penolakan dari keluarga korban menjadi sangat besar karena ketidak mampuan penyidik untuk meyakinkan korban bahwa pelaku akan dididik dengan baik dan tidak akan mengulangi tindak pidana di masa mendatang.

\section{Faktor Pendukung Penerapan Upaya Diversi Dalam penyelesaian tindak Pidana Pencurian yang Dilakukan Oleh Anak di Kabupaten Buleleng}

Polisi dalam melakukan

penyelidikan terhadap anak pelaku tindak pidana harus memperhatikan berbagai ketentuan mengenai upaya penangan anak mulai dari penangkapan sampai proses penempatan. Penyidikan terhadap tindak pidana pencurian harus berlangsung dalam suasana kekeluargaan, dan untuk itu penyidik wajib meminta pertimbangan atau saran dari Pembimbing Kemasyarakatan sesuai Undang-Undang No. 3 Tahun 1997.

Salah satu jaminan terlaksananya suasana kekeluargaan ketika penyidikan dilakukan, adalah hadirnya Pekerja sosial untuk mendampingi anak, disamping itu, karena yang disidik adalah anak, maka juga sebenarnya sangat penting kehadiran orang tua/wali/orang tua asuhnya, agar tidak timbul ketakutan atau trauma pada diri si anak. Apabila dipandang perlu, penyidik juga dapat meminta pertimbangan atau saran dari ahli pendidikan, ahli kesehatan jiwa, ahli agama, atau petugas kemasyarakatan lainnya. Sementara untuk kepentingan si anak sendiri, maka proses penyidikan wajib dirahasiakan. mekanisme

penyelesaian penerapan diversi terhadap tindak pidana pencurian oleh anak dibawah umur menggunakan mediasi atau musyawarah dengan menekankan pemulihan kembali pada keadaan semula dalam menyelesaikan konflik anak. Penyelesaian secara musyawarah ini tidak akan terealisasikan apabila tidak ada kerjasama antara korban, pelaku tindak pidana, masyarakat dan penyidik.

Diversi sebagai jalan didalam restorative justice, terdapat hal positif dalam menanggulangi tindak pidana pencurian khususnya tindak pidana pencurian yang dilakukan oleh anak di bawah umur, diantaranya:

a. Korban dapat mengungkapkan keluhanya, ketidaknyamanannya, dilain sisi dia dapat belajar tentang pelaku, cara menghadapi tindakan kejahatan pencurian, berkesempatan dan berhak mendapatkan permintaan maaf serta ganti rugi yang sesuai dari pelaku, menunjukan dampak kepada pelaku atas dampak yang ditimbulkan atas perbuatan pelaku, menyelesaikan semua konflik yang ada untuk kepentingan pribadi atau pemulihan.

b. Bagi pelaku dia memiliki rasa tanggung jawab atas apa yang dia lakukan terhadap korban, dan berhak meminta maaf serta membayar kerugian korban, kerja sosial sesuai kesepakatan yang disepakati dalam proses mediasi.

Dalam proses diversi mengharuskan adanya pengakuan bersalah terlebih dahulu (Hutauruk, 2013,127).Setelah adanya pengakuan bersalah dari pelaku tindak pidana, penyidik juga harus melihat motivasi dari pelaku melakukan tindak pidana pencurian, apakah pada dasarnya anak ini adalah jahat, dan sebelumnya pernah melakukan tindakantindakan yang merugikan orang lain, ataukah dengan keadaan sedemikian rupa, adanya keterpaksaan dalam melakukan tindak pidana pencurian.

Selain motifasi penyidik harus melihat nominal yang telah dicuri, serta membedakan mana kasus pencurian yang 
harus dibawa sampai ke pengadilan (pencurian berat Pasal 363 KUHPid), dan mana kasus pencurian yang seharusnya tidak dibawa ke pengadilan (pencurian ringan Pasal 364 KUHPid). Hal ini sangat penting karena banyak kasus-kasus pencurian yang dilakukan anak yang tergolong dalam pencurian ringan (Pasal 364 KUHP) hanya karena adanya bukti dan laporan dari korban serta adanya niat balas dendam sehingga kasus-kasus seperti ini berujung pada pemidanaan sampai mendapat putusan pidana penjara bertahuntahun.

Sehingga sangat diperluakan suatu upaya diversi untuk menghindari anak dari proses peradilan, namun pelaksanaan hasil kesepakatan upaya diversi tidak hanya dilakukan hanya mengalihkan perkara anak dari proses peradilan ke keluar pengadilan, namun seharusnya ada tindakan lanjutan, hal ini dikatakan oleh ibuk wiratningsih selaku kanit unit PPA.

\section{Simpulan}

Berdasarkan hasil penelitian dan pembahasan yang diuraikan oleh penulis maka dapat disimpulkan sebagai berikut:

1. Pelaksanaan upaya diversi dalam penyelesaian tindak pidana pencurian yang dilakukan oleh anak di kabupaten buleleng pada tingkat penyidikan di polres Buleleng sudah menerapkan upaya diversi sesuai dengan apa yang di amanatkan dalam Undang-Undang Nomor 11 Tahun 2012 tentang Sistem Peradilan Pidana Anak dan sudah menerapkan sesuai dengan Peraturan Pemerintah Republik Indonesia Nomor 65 Tahun 2015 tentang Pedoman Pelaksanaan. Dalam penerapan upaya diversi penyelesaian tindak pidana pencurian yang dilakukan oleh anak di kabupaten buleleng diversi sangat baik dialkukan selama hasilnya nanti setelah penetapan diversi anak tidak mengulangi perbuatannya lagi dan tidak meremehkan hasil dari diversi. Tetapi tidak semua kesepakatan diversi berhasil ada juga upaya diversi yang tidak berhasil dilakukan, hal ini dikarenakan dipicu oleh faktor korban yang masih belum bisa menerima dengan apa yang dilakukan oleh pelaku terhadap korban. Dapat juga dari pihak korban terkadang meminta ganti rugi materi kepada pihak pelaku, tetapi dari pihak pelaku tidak mampu memberikan dan memenuhi apa yang menjadi kemauan dari pihak korban.

2. Adapun faktor penghambat dari penerapan upaya diversi dalam penyelesaian tindak pidana pencurian yang dilakukan oleh anak di kabupaten buleleng yaitu, karena pelaksanaan diversi merupakan sebuah perjalanan yang terhitung baru, dalam pelaksanaannya seringkali menghadapi beberapa hambatan yaitu pemahaman terhadap pengertian diversi, batasan kebijakan aparat pelaksana diversi, dan kepercayaan masyarakat terhadap aturan pelaksanaan diversi dan hambatannya, sedangkan faktor pendukung penerapan upaya diversi dalam penyelesaian tindak pidana pencurian yang dilakukan oleh anak di kabupaten buleleng yaitu, dalam melakukan penyelidikan dan penyidikan terhadap anak pelaku tindak pidana harus memperhatikan berbagai ketentuan mengenai upaya penangan anak mulai dari penangkapan sampai proses penempatan. Penyidikan terhadap tindak pidana pencurian harus berlangsung dalam suasana kekeluargaan, dan untuk itu penyidik wajib meminta pertimbangan atau saran dari Pembimbing Kemasyarakatan sesuai Undang-Undang No. 3 Tahun 1997.

\section{Saran}

1. Pihak kepolisian selaku aparat penegak hukum yang pertama memeriksa perkara tindak pidana pencurian yang dilakukan oleh anak agar lebih meningkatkan penyuluhan tentang diversi, agar masyarakat memahami penerapan diversi bagi anak pelaku tindak pidana pencurian, sehingga nantinya lebih banyak lagi proses diversi yang berhasil mewujudkan kesepakatan antara pihak yang berperkara agar konsep keadilan restorative yang ingin dicapai dari proses diversi dapat terlaksanak dengan optimal.

2. Kepada masyarakat kabupaten Buleleng agar lebih peduli dan ikut membantu penerapan upaya diversi dengan ikut serta memahami bagaimana konsep upaya diversi yang dapat memberikan dampak positif bagi anak yang 
berhadapan dengan hukum. Sehingga anak yang berhadapan dengan hukum dihindarkan dari proses peradilan yang menakutkan bagi anak.

\section{Daftar Pustaka}

Buku

Bambang Waluyo, S.H. 2008 Penelitian Hukum Dalam Praktek. Jakarta : Sinar Grafika.

Sinaga, Dahlan, 2017, Penegakan hukum dengan Pendekatan Diversi, Nusa Media Yogyakarta, Yogyakarta.

Soekanto, soerjono, 1983, Soerjono, FaktorFaktor Yang Mempengaruhi Penegakan Hukum, Penerbit Rajawali Pers Cetakan ke 10.

\section{Skripsi / tesis}

Ferederica, Rafflesia, 2017, "Penerapan upaya Diversi Terhadap Anak Pelaku Penyalahgunaan Narkotika(studi Surat Keputusan Diversi Nomor:03/SKD/X/2014/Reskrim Polsek Kedaton)" (Skripsi), Program studi Sarjana Pada Bagian hukum Pidana Universitas Lampung, Bandar Lampung.

Yuliartini, Rai Ni Putu, 2014, "Kajian Kriminologis Kenakalan Anak Dalam Fenomena Balapan Liar Di Kota Singaraja Bali" (Tesis), Program Studi IImu Hukum Program Pascasarjana Universitas Udayana, Denpasar.

Zaimir, Fahmi, 2014, "Peran Penyidik Dalam Penerapan Diversi Terhadap Perkara Tindak Pidana Anak di Wilayah Kota Makasar"(Skripsi), Program studi Sarjana Pada Bagian hukum Pidana Makasar. Universitas hasanuddin,

\section{Jurnal / artikel di internet}

Humau, Kemal, 2013, "Implementasi Diversi Dalam Penyelesaian Kasus Tindak Pidana Yang Dilakukan Oleh Anak Sebelum Berlakunya Undang- Undang Republik Indonesia Nomor 11 Tahun 2012 Tentang Sistem Peradilan Pidana Anak" (Jurnal), Program Studi sarjana Universitas Atma jaya Yogyakarta, Yogyakarta.
Harefa, Beniharmoni, 2015, “Diversi Sebagai Perlindungan Hukum Terhadap Hak Asasi Anak Dalam Sistem Peradilan Pidana Anak Di Indonesia" (Jurnal), Pascasarjana Program Doktor FH UGM Yogyakarta, Yogyakarta.

\section{Peraturan perundang-undangan}

Kitab Undang-Undang Hukum Pidana

Kitab Undang-Undang Hukum Acara

Pidana

Kitab Undang-Undang Hukum Perdata

Undang-Undang Republik Indonesia Nomor 11 Tahun 2012 Tentang Sistem Peradilan Pidana Anak. Lembaran Negara Republik Indonesia Tahun 2012 Nomor 15352 dan Tambahan Lembaran Negara Republik Indonesia Nomor 5332.

Undang-Undang Republik Indonesia Nomor 35 Tahun 2014 Tentang Perlindungan Anak. Lembaran Negara Republik Indonesia Tahun 2002 Nomor 109 dan Tambahan Lembaran Negara Republik Indonesia Nomor 4235.

Undang-Undang Nomor 1 Tahun 1974 Tentang Perkawinan. Lembaran Negara Tahun 1974 Nomor 1, Tambahan Lembaran Negara Nomor 301.

Undang-Undang Nomor 4 Tahun 1979

Tentang Kesejahteraan Anak.

Lembaran Negara Tahun 1974 Nomor 53, Tambahan Lembaran Negara Nomor 3039.

Undang-Undang Nomor 39 Tahun 1999 Tentang Hak Asasi Manusi. Lembaran Negara Republik Indonesia Tahun 1999 Nomor 165, Tambahan Lembaran Negara Republik Indonesia Nomor 3886.

Peraturan Pemerintah Republik Indonesia Nomor 65 Tahun 2015 Tentang Pedoman Pelaksanaan Diversi Dan Penanganan Anak Yang Belum Berumur 12 (Dua Belas) Tahun.

\section{Kamus}

Pusat Bahasa Departemen Pendidikan Nasional, 2008, Kamus Besar Bahasa Indonesia, Edisi ke-4, Balai Pustaka, Jakarta 